Bangladesh J. Bot. 47(4): 863-875, 2018 (December)

\title{
PHYSIOLOGICAL AND BIOCHEMICAL RESPONSES OF BARLEY TO APPLICATION OF BIO-FERTILIZERS AND NANO IRON OXIDE UNDER SALINITY STRESS IN GREENHOUSE
}

\author{
Siyamak Dadashzadeh, Raouf Seyed Sharifi* and Salim Farzaneh \\ Department of Agronomy and Plant Breeding, Faculty of Agriculture and Natural Resources, \\ University of Mohaghegh Ardabili, Ardabil, Iran \\ Keywords: Antioxidant enzymes, Quantum yield, Proline, Salinity, Soluble sugars
}

\begin{abstract}
To study the effects of bio-fertilizers and nano iron oxide on some physiological and biochemical traits of barley under salinity stress, a factorial experiment was conducted based on RCBD with three replications under greenhouse condition. Factors in the study, included four levels of salinity, four levels of nano iron oxide use and four preparations of bio-fertilizer application. Increasing salinity in the soil decreased chlorophyll content, quantum yield, relative water content and grain yield, whereas soluble sugars, proline content, electrical conductivity and the activities of catalase, peroxidase and polyphenol oxidase enzymes increased. Inoculation of plants with bio-fertilizers and nano iron oxide application improved these traits (except electrical conductivity) under salinity as well as normal conditions. Results showed that application of Azospirillum and mycorrhiza and $0.9 \mathrm{~g} / \mathrm{l}$ nano iron oxide $\left(\mathrm{B}_{3} \mathrm{Fe}_{3}\right)$ increased about $15.45 \%$ from grain yield in comparison with $\mathrm{B}_{4} \mathrm{Fe}_{4}$ under the highest salinity level. Based on the results, it seems that bio-fertilizers and nano iron oxide application can be useful in alleviating salinity stress in barley.
\end{abstract}

\section{Introduction}

Salinity is one of the important and adverse environmental constraints restricting growth and development of plant particularly in arid and semiarid regions. Soil salinity induces water stress, nutritional imbalance, hormonal imbalance and generation of reactive oxygen species (ROS) which may cause membrane destabilization (Omar et al. 2009). Moreover, it decreases the yield of many crops by inhibiting plant photosynthesis, photosystem II efficiency (Netondo et al. 2004), protein synthesis and lipid metabolism. Mittova et al. (2003) reported that the activities of the antioxidative enzymes such as CAT and SOD increased under salt stress in plants. One approach to solve the salt stress problem is the use of plant growth promoting rhizobacteria (PGPR) and mycorrhiza. The PGPR are a group of rhizosphere colonizing bacteria that produce substances to increase the growth of plants, synthesize different phytohormones, synthesize enzymes, including phosphatase, catalase that can modulate plant growth and development (Glick 2012). Wang et al. (2012) found that inoculation of PGPR strains improved plant enzyme activity, which alleviates the oxidative damage induced by drought and salinity. Seyed et al. (2016) reported that inoculation with PGPR enhanced proline content, relative water content, and photochemical efficiency of PSII and the activity of antioxidant enzymes of wheat under salinity stress. Large number of plant species are capable of forming symbiotic associations with arbuscular mycorrhizal fungi (Glassop et al. 2005). They also impart other benefits to them, including production/accumulation of secondary metabolites, osmotic adjustment under osmotic stress, enhanced photosynthesis rate and increased resistance against biotic and abiotic stresses (Willis et al. 2013). They are also interactive with different soil bacteria. AM hyphae are able to produce $\mathrm{C}$ products in a little amount as a source of energy for soil microbes in the mycorrhizosphere. Bacterial communities are able to promote germination of AM fungal spores and increase the rate

*Author for correspondence.<raouf_ssharifi@yahoo.com>. 
and extent of root plant colonization by AM fungi. Also, soil microbes produce plant hormones, which can influence AM establishment as well as spore and hyphal growth (Miransari 2011). Qun et al. (2007) reported that AM-inoculated seedlings maintained higher activities of SOD, CAT and POD as compared to un-inoculated seedlings under salinity stress. Mycorrhizal fungi increase the sugar content of the host plant by hydrolysis of starch to sugars and preventing structural changes in soluble protein (Kapoor et al. 2013).

Iron is an important component of many vital enzymes such as CAT and SOD, and also participates in the synthesis of chlorophyll, electron transport and photosynthesis (Jeong and Connolly 2009). Babaei et al. (2017) reported that microelements application such as iron and zinc increased the proline content, chlorophyll content, soluble sugars, antioxidant enzyme activity and yield of wheat under salinity stress. The problem of soil salinization is a scource for agricultural productivity worldwide. Also iron deficiency is a common nutritional disorder in many crop plants, resulting in poor yields and reduced nutritional quality. Application of bio-fertilizers and iron is one of the most important strategies for alleviation of salinity stress effects. Therefore, the aim of this study was to evaluate the effects of bio-fertilizers and iron on some physiological and biochemical responses of barley under salinity stress conditions.

\section{Materials and Methods}

A factorial experiment based on RCBD with three replications was conducted under greenhouse condition in 2016. Experimental factors were salinity in four levels [no-salt (control or $\left.\mathrm{S}_{1}\right)$, salinity $25\left(\mathrm{~S}_{2}\right), 50\left(\mathrm{~S}_{3}\right)$ and $\left.75\left(\mathrm{~S}_{4}\right) \mathrm{mM} \mathrm{NaCl}\right)$ ], four bio-fertilizers levels [(Azospirillum $\left(\mathrm{B}_{1}\right)$, mycorrhiza $\left(\mathrm{B}_{2}\right)$, both application Azospirillum and mycorrhiza $\left(\mathrm{B}_{3}\right)$ and no bio-fertilizer $\left.\left(\mathrm{B}_{4}\right)\right]$ and four nano iron oxide levels [application of $0.3\left(\mathrm{Fe}_{1}\right), 0.6\left(\mathrm{Fe}_{2}\right), 0.9\left(\mathrm{Fe}_{3}\right) \mathrm{g} / 1$ and without nano iron oxide as control $\left.\left(\mathrm{Fe}_{4}\right)\right]$. The studied area soil was silty loam, Haplic Cambisol according to World Reference Base (WRB 2014), with $\mathrm{pH}$ about 6.7, total organic C $-0.074 \%, \mathrm{Fe}-5.35 \mathrm{mg} / \mathrm{kg}$ soil. Air temperature ranged from $24-2^{\circ} \mathrm{C}$ during the day and $17-20^{\circ} \mathrm{C}$ during the night. Humidity ranged from $60-65 \%$ (Seyed Sharifi et al. 2016). The barley cultivar Valfajr' was used in the experiment. Optimal density of cultivar 'Valfajr' is $400 \mathrm{seeds} / \mathrm{m}^{2}$, so 40 seeds were sown in each pot, filled approximately with $18 \mathrm{~kg}$ of above mentioned soil. Salt stress treatments were applied in two stages [immediately after planting and two weeks after planting (at 3 - 4 leaf stage)]. Foliar application with nano iron oxide was done in two stage (4 - 6 leaves stages and before of booting stages) of period growth. Mycorrhiza fungi (Glomus intraradices) was purchased from the Zist Fanavar Turan institute and soils were treated based on the manufacturer's protocol $10 \mathrm{~g}$ of inoculums per $1 \mathrm{~kg}$ soil, each pot containing approximately 865 spores. Azospirillum lipoferum strain of was isolated from the rhizospheres of wheat by Research Institute of Soil and Water, Tehran, Iran. The strains and cell densities of microorganisms used as PGPR in this experiment were $10^{8}$ colony forming units (CFU). At the mid of booting stage, the flag leaves of plants were separated for measuring the following determinations (Zayed et al. 2014).

At the mid of the booting stage, the flag leaves of plants were separated. Samples were placed in aluminum foil and transported from the field on ice bath. Catalase, peroxidase and polyphenol oxidase activity was assayed according to Karo and Mishra (1976).

Method of Bates et al. (1973) was used to measure the proline. Soluble sugars were determined based on phenol sulphuric acid method (Dubois et al. 1956).

A portable chlorophyll meter (SPAD-502; Konica Minolta Sensing, Inc., Japan) was used to measure the leaf greenness of the barley plants. For each plant, measurements were taken at three locations on each leaf, and four plants per treatment were evaluated. The quantum yield was measured by the uppermost fool expanded leaf using a fluorometer (chlorophyll fluorometer; 
Optic Science-OS-30 USA). For this purpose, the plants adapted to darkness for 20 minutes by using one special clamp then the fluorescence amounts were measured in $1000\left(\mu \mathrm{M}\right.$ photon $\left.\mathrm{m}^{2} \mathrm{~s}\right)$, and calculation was done using following formula (Kheirizadeh Arough et al. 2016): ØPSII = $(\mathrm{Fm}-\mathrm{F} 0) / \mathrm{Fm}$

Quantum yield amount of photosystem II, Fm or maximum fluorescence after a saturated light pulse on plants adapted to darkness and $\mathrm{F}_{0}$, the minimal fluorescence in the light adapted were determined by illumination with far-red light.

Relative water content was estimated according to the method of Tambussi et al. (2005). Electrical conductivity was calculated according the method of Jodeh et al. (2015).

In order to measure grain yield, 10 plants of each pot randomly were harvested. Analysis of variance and mean comparisons were performed using $\mathrm{SAS}_{9.1}$ computer software packages. The main effects and interactions were tested using LSD test at the 0.05 probability level.

\section{Results and Discussion}

Results showed that the activity of CAT, POD and PPO enzymes increased with the increase of salinity stress, application of bio fertilizers and nano iron oxide in comparison with control (Table 1). In the present results, increase in activities of CAT and POD as a result of salt stress is in concurrence with the findings of Kheirizadeh Arough et al. (2016) for triticale. The highest activity of CAT (193.35 OD $\mu \mathrm{g}$ protein $\left.\mathrm{min}^{-1}\right)$, POD (80.49 OD $\mu \mathrm{g}$ protein $\left.\mathrm{min}^{-1}\right)$ and PPO (65.83 OD $\mu \mathrm{g}$ protein $/ \mathrm{min}$ ) were observed in $\mathrm{S}_{4} \mathrm{~B}_{3} \mathrm{Fe}_{3}$ (Table 2). There were an increase about 4.71, 39.76 and $47.83 \%$ in activity of CAT, POD and PPO enzymes, respectively in the highest salinity level, application of bio fertilizers and nano iron oxide $\left(\mathrm{S}_{4} \mathrm{~B}_{3} \mathrm{Fe}_{3}\right)$ in comparison with $\mathrm{B}_{4} \mathrm{Fe}_{4}$ in the same salinity level (Table 2). When plants are subjected to various abiotic stresses, some ROS such as superoxide $\left(\mathrm{O}^{2-}\right)$, hydrogen peroxide $\left(\mathrm{H}_{2} \mathrm{O}_{2}\right)$, hydroxyl radicals $\left(\mathrm{OH}^{-}\right)$and singlet oxygen are produced (Bor et al. 2003). To be able to control the level of ROS and to protect cells under stress conditions, plant tissues have several enzymes scavenging ROS such as peroxidases (POD), polyphenol oxidase (PPO) and catalase (CAT) (Seyed Sharifi et al. 2016).

Enhancement in antioxidant enzyme activity under stress conditions helps in quick scavenging of ROS and maintaining their levels below the deleterious levels (Hashem et al. 2015). Our results showed that application of Azospirillum and mycorrhiza increased about $3.37 \%$ in CAT, $14.9 \%$ in POD and $19.24 \%$ in PPO activity, in comparison with no-bio fertilizer (Table 1). The impact of nano iron oxide on activity of CAT and PPO and POD were similar to biofertilizers. So, there was an increase about $0.23,18.05$ and $8.64 \%$ in activity of CAT, POD and PPO respectively by foliar spraying $0.9 \mathrm{~g} / 1$ nano iron oxide in comparison to control (Table 1).

Hashem et al. (2015) reported that the activities of antioxidant enzymes such as superoxide dismutase (SOD), catalase (CAT) and peroxidase (POD) increased by salt stress and were further enhanced by AMF inoculation. Iron is an essential mineral for plants that is required for biological redox systems, and it is also a vital component of many enzymes that play important roles in the physiological and biochemical processes of plants. It acts as a cofactor of key enzymes involved in plant hormone synthesis (Jeong and Connolly 2009).

Proline content significantly increased under salinity stress. Inoculation with Azospirillum, mychorrhiza and both these bio-fertilizers under salinity stress increased proline content. In addition, the proline content significantly increased when nano iron oxide was applied. Interaction effect among salinity, bio-fertilizers and nano iron oxide showed that the highest content of proline $(5.64 \mu \mathrm{g} / \mathrm{g} \mathrm{FW})$ was obtained in $\mathrm{S}_{4} \mathrm{~B}_{3} \mathrm{Fe}_{3}$ (Table 3). The minimum of proline $(1.56 \mu \mathrm{g} / \mathrm{g}$ FW) was observed in $\mathrm{S}_{1} \mathrm{~B}_{4} \mathrm{Fe}_{4}$ (Table 3). Results showed that at the highest salinity level, application of bio-fertilizers as $\mathrm{B}_{3}$ and nano iron oxide as $\mathrm{Fe}_{3}$ increase about $37.22 \%$ in content of 


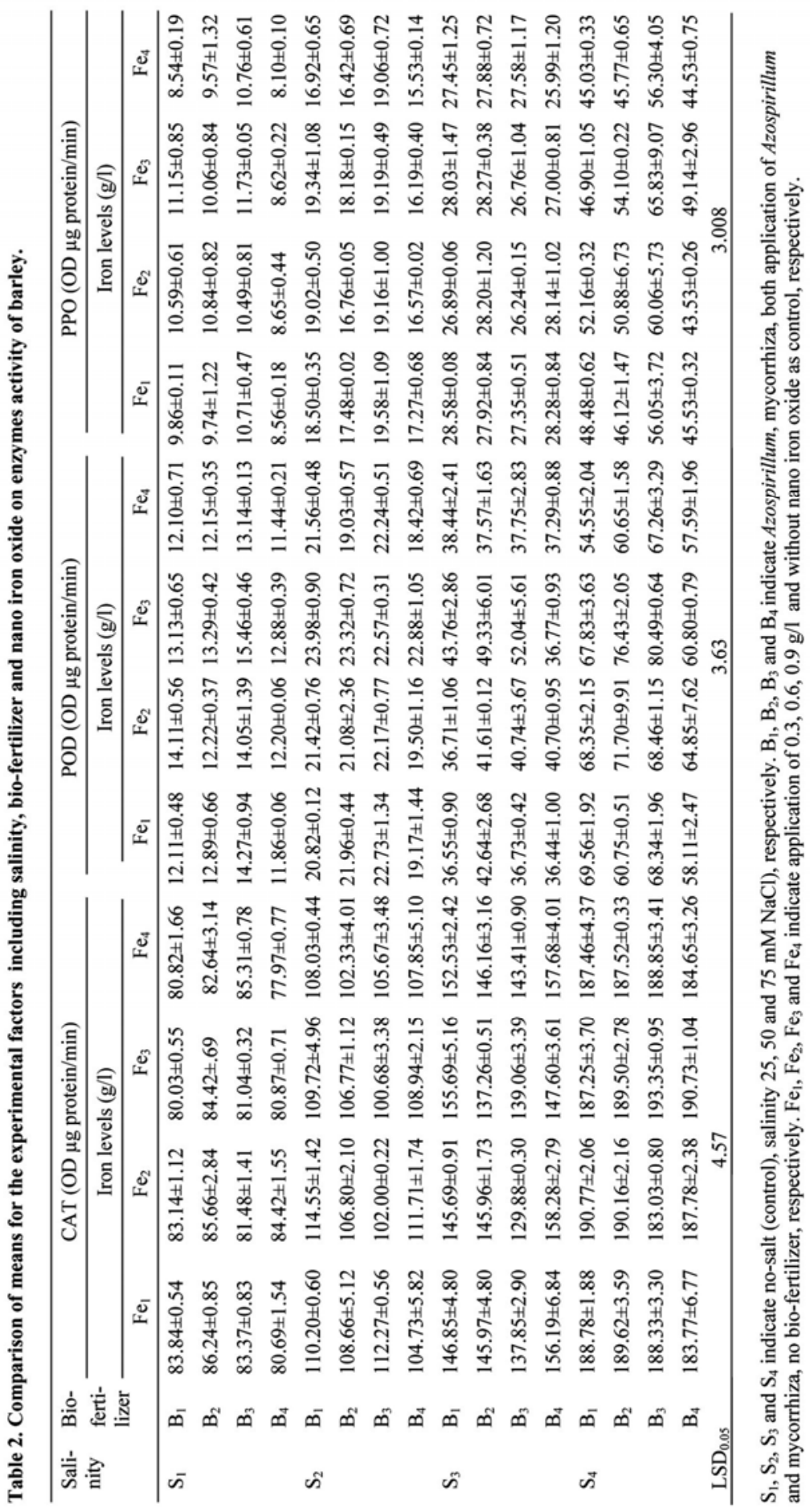


proline in comparison to $\mathrm{B}_{4}$ and $\mathrm{Fe}_{4}$ in the same salinity level (Table 3). Increased accumulation of compatible organic solutes such as proline is one of the important traits determining the tolerance potential of plants. Studies showed that proline and soluble sugars accumulation in plants were performed by different methods including: stimulating of synthesis from pre-material, reducing of proline oxidasE activity, proteins destruction and reducing of proteins structure partnership (Yordanov Arough et al. 2003). Observation of increase in proline due to AMF is in agreement with the findings of Kheirizadeh et al. (2016) for Triticale. The highest content of soluble sugars (97.07, 61.35 and $58.53 \mathrm{mg} / \mathrm{g} \mathrm{FW}$ ) were observed in salinity of $75 \mathrm{mM} \mathrm{NaCl}$, application of Azospirillum and mycorrhiza and $0.9 \mathrm{~g} / 1$ nano iron oxide, respectively (Table 1). Interaction effect between salinity and nano iron oxide showed that the highest content of soluble sugars (105.39 $\mathrm{mg} / \mathrm{g} \mathrm{FW}$ ) was obtained in severe salinity stress and $0.9 \mathrm{~g} / 1$ nano iron oxide (Table 4). There were increases about $18.5 \%$ in content of soluble sugars content in the $\mathrm{S}_{4} \mathrm{Fe}_{3}$ in comparison to $\mathrm{S}_{4} \mathrm{Fe}_{4}$ (Table 4). Also interaction effect between salinity and bio-fertilizers indicate that the highest content of soluble sugars $(110.59 \mathrm{mg} / \mathrm{g} \mathrm{FW})$ was observed in $\mathrm{S}_{4} \mathrm{~B}_{3}$ (Table 4). The lowest of it $(20.86 \mathrm{mg} / \mathrm{g} \mathrm{FW})$ was obtained in $\mathrm{S}_{1} \mathrm{~B}_{4}$ (Table 4). On the other hand, at the highest salinity level, application of both Azospirillum and mycorrhiza increased 32.64\% in soluble sugars content in comparison to control (Table 4). Increase of sugar under environmental stress was recognized as a result of starch degradation, sugar synthesis by non-photosynthesis pathways, non-converting of these components to other productions and decreasing of transporting from leaves (Premachandre et al. 1991). AMF fungi significantly increased photosynthetic of host plants and thereby caused an increase in sugar content (Feng et al. 2002). Babaei et al. (2017) reported that PGPR and nano iron oxide increased the proline and soluble sugars content of wheat under salinity stress.

Results showed that the quantum yield and chlorophyll content decreased under salinity stress. While application of bio-fertilizers and nano iron oxide increased these traits. The highest chlorophyll index (55.2) and quantum yield (0.870) were obtained in $\mathrm{S}_{1} \mathrm{~B}_{3} \mathrm{Fe}_{3}$, while the lowest (38.73 and 0.566, respectively) was obtained in $\mathrm{S}_{4} \mathrm{~B}_{4} \mathrm{Fe}_{4}$ (Table 5). Under the highest salinity level, application of bio-fertilizers as $\mathrm{B}_{3}$ and foliar spraying as $\mathrm{Fe}_{3}$ increased about $13.42 \%$ in chlorophyll index and $13.42 \%$ in quantum yield, in comparison to $\mathrm{B}_{4}$ and $\mathrm{Fe}_{4}$ in the same salinity level (Table 5). Reduction in chlorophyll index due to salinity stress is more or less similar to the findings of Seyed Sharifi et al. (2016) in wheat, and Kheirizadeh et al. (2016) in Triticale. The main reason for the decrease in chlorophyll might be due to degradation by reactive oxygen species (ROS) (Navari-Izzo et al. 1990). Increase in the synthesis of proline also led to a decrease in the chlorophyll content in salinity condition. Reduction of chlorophyll content finally resulted in the decrease in the efficiency of photosynthesis. A decrease in this ratio results from photosynthetic electron transport impairment (Pereira et al. 2000). Reduced chlorophyll content under stress is attributed to increased activity of chlorophyllase causing degradation of pigments (Hashem et al. 2015). Seyed Sharifi et al. (2007) reported that salt stress decreased chlorophyll content of wheat, but inoculation with bio-fertilizers increased the chlorophyll pigments.

Kaya et al. (2009) demonstrated that inoculation of AMF increased chlorophyll content under normal as well as salt-stressed conditions. Injury to PSII can lead to a change in chlorophyll fluorescence. Thus, chlorophyll fluorescence has been used as a powerful and reliable noninvasive method for assessing the changes in the function of PSII and for reflecting the primary photosynthetic processes under environmental stress conditions (Maxwell and Johnson 2000). Arbuscular mycorrhizal fungus plays a role in $\mathrm{Fv} / \mathrm{Fm}$ increase by improving plants nutritional status and activating mediated genes (Sayar et al. 2008). Saito et al. (2014) demonstrate that Fe deficiency decreased the PSII content of barley. 
Table 3. Comparison of means for the experimental factors including salinity stress, bio-fertilizers and nano iron oxide on proline content of barley.

\begin{tabular}{|c|c|c|c|c|c|}
\hline \multirow{3}{*}{ Salinity } & \multirow{3}{*}{ Bio-fertilizers } & \multicolumn{4}{|c|}{ Proline $(\mu \mathrm{g} / \mathrm{g} \mathrm{FW})$} \\
\hline & & \multicolumn{4}{|c|}{ Iron levels $(\mathrm{g} / \mathrm{l})$} \\
\hline & & $\mathrm{Fe}_{1}$ & $\mathrm{Fe}_{2}$ & $\mathrm{Fe}_{3}$ & $\mathrm{Fe}_{4}$ \\
\hline \multirow{4}{*}{$\mathrm{S}_{1}$} & $\mathrm{~B}_{1}$ & $1.88 \pm 0.04$ & $1.94 \pm 0.02$ & $1.93 \pm 0.02$ & $1.80 \pm 0.02$ \\
\hline & $\mathrm{B}_{2}$ & $1.85 \pm 0.01$ & $1.93 \pm 0.02$ & $1.95 \pm 0.02$ & $1.79 \pm 0.02$ \\
\hline & $\mathrm{B}_{3}$ & $2.00 \pm 0.02$ & $2.01 \pm 0.03$ & $2.02 \pm 0.03$ & $1.91 \pm 0.02$ \\
\hline & $\mathrm{B}_{4}$ & $1.65 \pm 0.02$ & $1.69 \pm 0.02$ & $1.83 \pm 0.02$ & $1.56 \pm 0.02$ \\
\hline \multirow{4}{*}{$\mathrm{S}_{2}$} & $\mathrm{~B}_{1}$ & $2.90 \pm 0.04$ & $2.92 \pm 0.04$ & $3.13 \pm 0.04$ & $2.83 \pm 0.03$ \\
\hline & $\mathrm{B}_{2}$ & $2.72 \pm 0.04$ & $2.84 \pm 0.04$ & $3.06 \pm 0.04$ & $2.69 \pm 0.04$ \\
\hline & $\mathrm{B}_{3}$ & $2.96 \pm 0.03$ & $3.12 \pm 0.04$ & $3.13 \pm 0.04$ & $2.87 \pm 0.04$ \\
\hline & $\mathrm{B}_{4}$ & $2.81 \pm 0.02$ & $2.83 \pm 0.05$ & $2.84 \pm 0.05$ & $2.66 \pm 0.03$ \\
\hline \multirow{4}{*}{$\mathrm{S}_{3}$} & $\mathrm{~B}_{1}$ & $3.58 \pm 0.05$ & $3.71 \pm 0.06$ & $3.72 \pm 0.07$ & $3.43 \pm 0.04$ \\
\hline & $\mathrm{B}_{2}$ & $3.58 \pm 0.05$ & $3.62 \pm 0.06$ & $3.65 \pm 0.05$ & $3.57 \pm 0.05$ \\
\hline & $\mathrm{B}_{3}$ & $3.69 \pm 0.04$ & $3.73 \pm 0.06$ & $3.72 \pm 0.05$ & $3.62 \pm 0.06$ \\
\hline & $\mathrm{B}_{4}$ & $3.42 \pm 0.07$ & $3.47 \pm 0.03$ & $3.64 \pm 0.06$ & $3.28 \pm 0.05$ \\
\hline \multirow{4}{*}{$\mathrm{S}_{4}$} & $\mathrm{~B}_{1}$ & $4.66 \pm 0.07$ & $4.65 \pm 0.06$ & $5.09 \pm 0.08$ & $4.27 \pm 0.06$ \\
\hline & $\mathrm{B}_{2}$ & $4.80 \pm 0.07$ & $5.16 \pm 0.06$ & $5.34 \pm 0.08$ & $4.32 \pm 0.06$ \\
\hline & $\mathrm{B}_{3}$ & $5.20 \pm 0.08$ & $5.39 \pm 0.06$ & $5.64 \pm 0.08$ & $4.99 \pm 0.06$ \\
\hline & $\mathrm{B}_{4}$ & $4.19 \pm 0.07$ & $4.55 \pm 0.08$ & $4.64 \pm 0.06$ & $4.11 \pm 0.06$ \\
\hline $\mathrm{LSD}_{0.05}$ & & & 0.03 & & \\
\hline
\end{tabular}

Table 4. Comparison of means for the experimental factors including salinity $\times$ nano iron oxide and salinity $\times$ biofertilizers on soluble sugars of barley.

\begin{tabular}{|c|c|c|c|c|c|c|c|}
\hline \multirow{3}{*}{$\begin{array}{l}\text { Sali- } \\
\text { nity }\end{array}$} & \multicolumn{7}{|c|}{ Soluble sugars (mg/g FW) } \\
\hline & \multicolumn{4}{|c|}{ Iron levels (g/l) } & \multicolumn{3}{|c|}{ Bio-fertilizers } \\
\hline & $\mathrm{Fe}_{1}$ & $\mathrm{Fe}_{2}$ & $\mathrm{Fe}_{3}$ & $\mathrm{Fe}_{4}$ & $\mathrm{~B}_{1}$ & $\mathrm{~B}_{3}$ & $\mathrm{~B}_{4}$ \\
\hline $\mathrm{S}_{1}$ & $24.03 \pm 2.48$ & $24.47 \pm 2.46$ & $25.12 \pm 2.20$ & $22.35 \pm 2.09$ & $24.17 \pm 1.39$ & $24.20 \pm 1.7926 .75 \pm 0.94$ & $20.86 \pm 1.00$ \\
\hline $\mathrm{S}_{2}$ & $35.70 \pm 2.10$ & $36.15 \pm 2.97$ & $37.59 \pm 3.10$ & $33.25 \pm 3.31$ & $36.01 \pm 1.31$ & $35.04 \pm 2.5238 .74 \pm 2.33$ & $32.90 \pm 3.41$ \\
\hline $\mathrm{S}_{3}$ & $59.90 \pm 6.73$ & $63.07 \pm 7.67$ & $66.03 \pm 10.77$ & $54.21 \pm 7.36$ & $59.32 \pm 7.29$ & $61.26 \pm 7.9969 .31 \pm 8.70$ & $53.31 \pm 4.76$ \\
\hline $\mathrm{S}_{4}$ & $97.13 \pm 15.13$ & $396.82 \pm 14.51$ & $1105.39 \pm 17.16$ & $688.93 \pm 12.23$ & $100.18 \pm 15.5$ & $194.14 \pm 9.32110 .59 \pm 14.2$ & $983.37 \pm 8.69$ \\
\hline \multicolumn{2}{|c|}{$\operatorname{LSD}_{0.05}$} & \multicolumn{3}{|c|}{6.94} & \multicolumn{3}{|c|}{5.79} \\
\hline
\end{tabular}

The RWC value decreased in barley plants when exposed to saline conditions, but EC content increased. The highest RWC (84.27\%) was obtained at no salinity, application of mycorrhiza and $0.9 \mathrm{~g} / 1$ nano iron oxide $\left(\mathrm{S}_{1} \mathrm{~B}_{2} \mathrm{Fe}_{3}\right)$ (Table 6). Whereas, the lowest RWC $(50.53 \%)$ was observed in salinity $75 \mathrm{mM}$ and control treatment $\left(\mathrm{B}_{4} \mathrm{Fe}_{4}\right)$ (Table 6). Application of bio- fertilizers as $\mathrm{B}_{3}$ and foliar spraying as $\mathrm{Fe}_{3}$ under salinity $75 \mathrm{mM}$ increased about $14.09 \%$ in RWC, in comparison to $\mathrm{B}_{4}$ and $\mathrm{Fe}_{4}$ in the same salinity level (Table 6). The highest EC $(469.14 \mu \mathrm{S} / \mathrm{cm}$ ) was observed at the highest salinity level, no application of bio-fertilizer and nano iron oxide $\left(\mathrm{S}_{4} \mathrm{~B}_{4} \mathrm{Fe}_{4}\right)$ (Table 6). There was a decrease of about $8.7 \%$ in content of electrical conductivity at the $\mathrm{S}_{4} \mathrm{~B}_{3} \mathrm{Fe}_{3}$ in comparison with $\mathrm{S}_{4} \mathrm{~B}_{4} \mathrm{Fe}_{4}$ (Table 6). Plant growth is dependent on water status of leaf, as salt and drought stress can create a water deficit inside plant tissues. The decrease in RWC could be related 


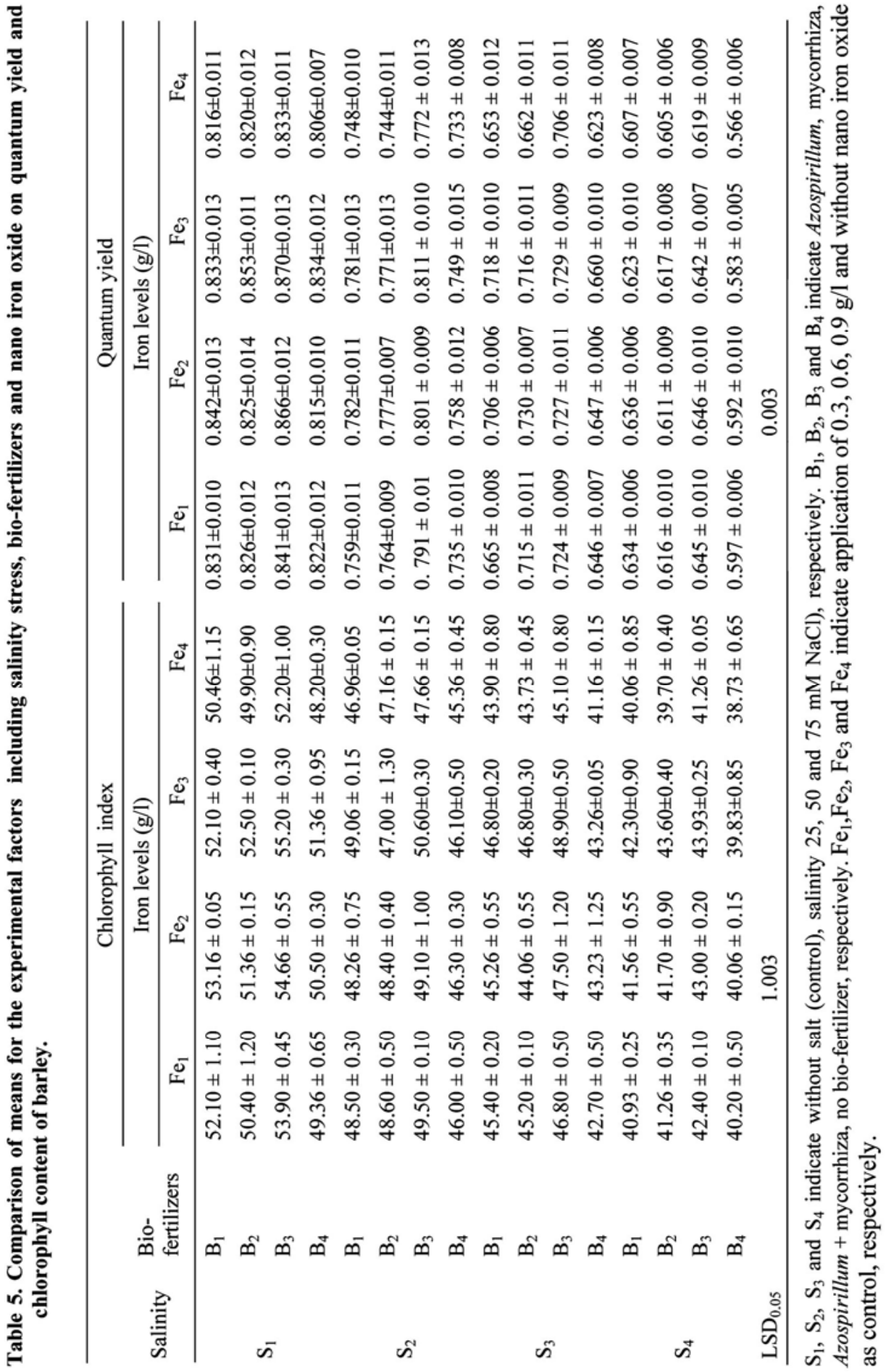




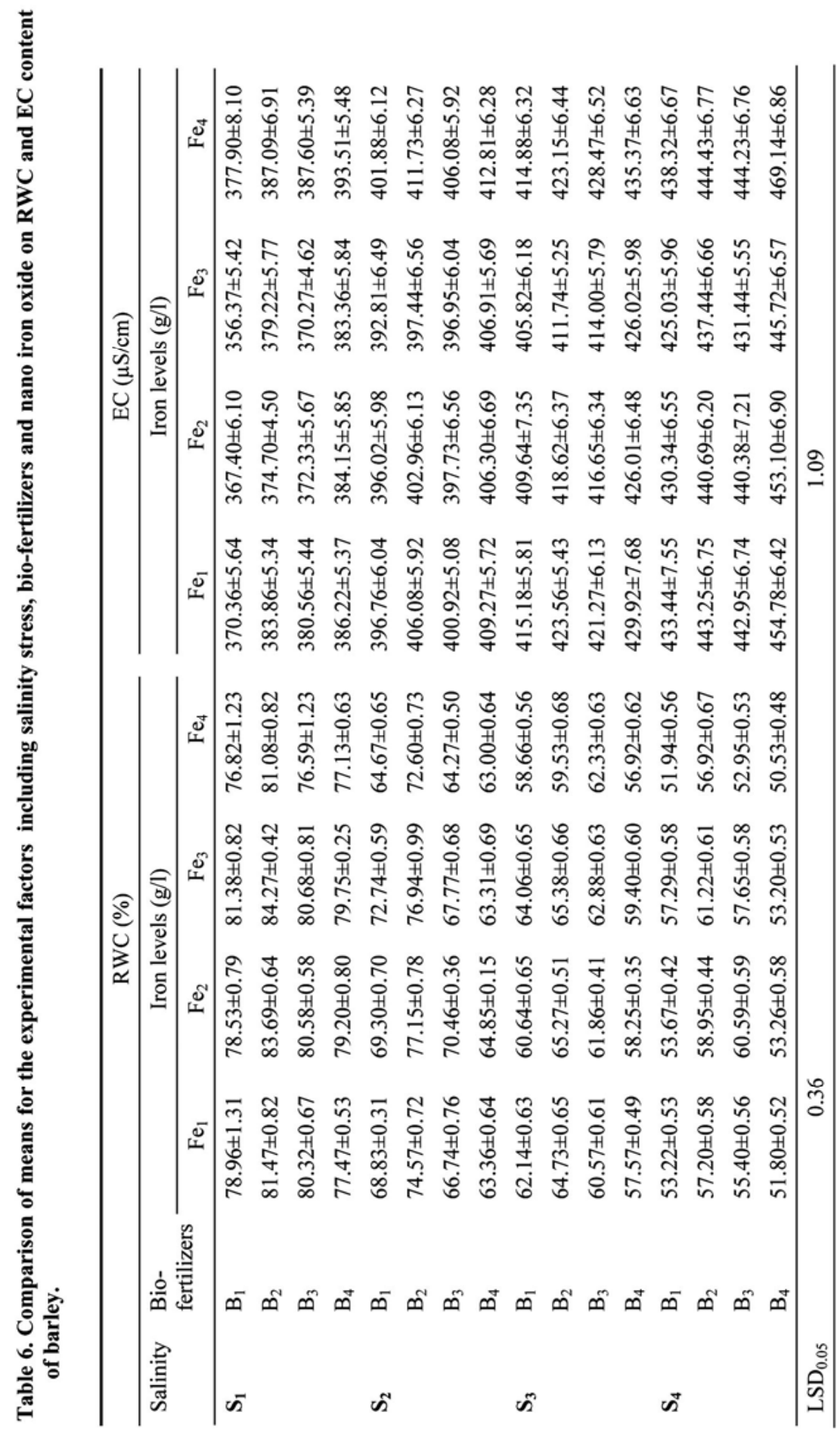


to low water availability under stress conditions or to root systems, which are not able to compensate water loss by transpiration through a reduction of the absorbing surface (Gadallah 2000). The RWC of PGPR-treated plants were observed to be higher than that of control during salinity stress. The present findings are in confirmatory with other studies (Babaei et al. 2017). Previous studies have found that mycorrhizal plants often show higher leaf RWC compared to non-mycorrhizal plants. Guo et al. (2010) reported that mycorrhizal roots can explore more soil volume due to their extra matrical hyphae that facilitate them for absorption and translocation of more nutrients than by non-mycorrhizal plants. Moreover, better water status might result in the increased activity and hydraulic conductivity of the roots. Dröge (2002) has reported that salinity at high concentrations, is a major factor that enhances the oxidative damage of membrane components and cell structures, which in turn could explain a higher value of EC in the highest

Table 7. Comparison of means for the experimental factors including salinity stress, bio-fertilizers and nano iron oxide on grain yield of barley.

\begin{tabular}{|c|c|c|c|c|c|}
\hline \multirow{3}{*}{ Salinity } & \multirow{3}{*}{ Bio-fertilizers } & \multicolumn{4}{|c|}{ Grain yield (g per plant) } \\
\hline & & \multicolumn{4}{|c|}{ Iron levels (g/l) } \\
\hline & & $\mathrm{Fe}_{1}$ & $\mathrm{Fe}_{2}$ & $\mathrm{Fe}_{3}$ & $\mathrm{Fe}_{4}$ \\
\hline \multirow{3}{*}{$\mathrm{S}_{1}$} & $\mathrm{~B}_{1}$ & $1.936 \pm 0.024$ & $1.987 \pm 0.035$ & $1.988 \pm 0.032$ & $1.871 \pm 0.016$ \\
\hline & $\mathrm{B}_{2}$ & $1.872 \pm 0.03$ & $1.937 \pm 0.022$ & $1.931 \pm 0.031$ & $1.855 \pm 0.018$ \\
\hline & $\mathrm{B}_{3}$ & $1.993 \pm 0.033$ & $2.02 \pm 0.028$ & $2.04 \pm 0.035$ & $1.977 \pm 0.036$ \\
\hline \multirow{5}{*}{$\mathrm{S}_{2}$} & $\mathrm{~B}_{4}$ & $1.853 \pm 0.025$ & $1.848 \pm 0.028$ & $1.915 \pm 0.025$ & $1.831 \pm 0.028$ \\
\hline & $\mathrm{B}_{1}$ & $1.842 \pm 0.032$ & $1.823 \pm 0.028$ & $1.844 \pm 0.029$ & $1.786 \pm 0.026$ \\
\hline & $\mathrm{B}_{2}$ & $1.834 \pm 0.026$ & $1.892 \pm 0.028$ & $1.87 \pm 0.029$ & $1.801 \pm 0.031$ \\
\hline & $\mathrm{B}_{3}$ & $1.868 \pm 0.031$ & $1.904 \pm 0.031$ & $1.914 \pm 0.03$ & $1.833 \pm 0.035$ \\
\hline & $\mathrm{B}_{4}$ & $1.737 \pm 0.027$ & $1.748 \pm 0.021$ & $1.831 \pm 0.028$ & $1.712 \pm 0.026$ \\
\hline \multirow{3}{*}{$\mathrm{S}_{3}$} & $\mathrm{~B}_{1}$ & $1.511 \pm 0.023$ & $1.452 \pm 0.027$ & $1.53 \pm 0.025$ & $1.445 \pm 0.023$ \\
\hline & $\mathrm{B}_{2}$ & $1.486 \pm 0.022$ & $1.522 \pm 0.027$ & $1.532 \pm 0.026$ & $1.484 \pm 0.021$ \\
\hline & $\mathrm{B}_{3}$ & $1.571 \pm 0.024$ & $1.573 \pm 0.028$ & $1.586 \pm 0.031$ & $1.568 \pm 0.027$ \\
\hline \multirow{5}{*}{$\mathrm{S}_{4}$} & $\mathrm{~B}_{4}$ & $1.44 \pm 0.018$ & $1.425 \pm 0.022$ & $1.459 \pm 0.025$ & $1.408 \pm 0.022$ \\
\hline & $\mathrm{B}_{1}$ & $1.382 \pm 0.02$ & $1.438 \pm 0.024$ & $1.47 \pm 0.024$ & $1.365 \pm 0.025$ \\
\hline & $\mathrm{B}_{2}$ & $1.42 \pm 0.022$ & $1.43 \pm 0.017$ & $1.423 \pm 0.023$ & $1.4 \pm 0.02$ \\
\hline & $\mathrm{B}_{3}$ & $1.505 \pm 0.025$ & $1.494 \pm 0.026$ & $1.524 \pm 0.026$ & $1.477 \pm 0.026$ \\
\hline & $\mathrm{B}_{4}$ & $1.353 \pm 0.017$ & $1.408 \pm 0.022$ & $1.382 \pm 0.02$ & $1.32 \pm 0.02$ \\
\hline $\mathrm{LSD}_{0.05}$ & & \multicolumn{4}{|c|}{0.007} \\
\hline
\end{tabular}

salinity level. Bano and Fatima (2009) observed that the salt tolerance in Zea mays inoculated with rhizobium and pseudomonas was mediated by the decrease in electrolyte leakage, increase in proline production and maintenance of water content of leaves with selective uptake of $\mathrm{K}^{+}$ions. Zago and Oteiza (2001) stated that iron element by increasing the activity of antioxidant systems in plants decreased reactive oxygen species injuries and plays an important role in membrane stability. 
The grain yield decreased in barley crop under salinity conditions. Results showed that inoculation with bio-fertilizers and foliar application of nano iron oxide under salinity stress significantly increased grain yield of barley. The highest grain yield (2.04 g per plant) was obtained in no-salinity, application of bio-fertilizer as $\mathrm{B}_{3}$ and nano iron oxide as $\mathrm{Fe}_{3}$ (Table 7). According to the results, the stimulatory effect of bio-fertilizer and nano iron oxide has been attributed to several mechanisms that increase plant yield, including enhanced RWC, proline, chlorophyll content, quantum yield and enhanced activity of PPO, POD and CAT in the leaves. Babaei et al. (2017) reported that salinity stress significantly decreased grain yield of wheat. One of the methods of increasing the plant growth and yield by PGPR is the ability to produce siderophore and increase the level of iron in the plant (Bhattacharyya and Jha 2012). Azcon and Barea (2010) have proposed co-inoculation PGPR and AM fungi as an efficient procedure to increase yield and plant growth.

The present research indicated that salinity stress reduced grain yield per plant, quantum yield and chlorophyll content of the plants. But antioxidant enzymes activity, soluble sugars and proline content increased. Also application of bio-fertilizer and nano iron oxide improved grain yield, RWC, quantum yield, chlorophyll content, antioxidant enzyme activity, proline and soluble sugars content under salinity condition. Application of bio-fertilizer and nano iron oxide can be recommended for profitable barley production under salinity condition.

\section{References}

Azcon R and Barea JM 2010. Mycorrhizosphere interactions for legume improvement. In: Khanf, M.S., Zaidi, A., Musarrat, J. Editors. Microbes for legume improvement. Vienna: Springer. p. 237-271.

Babaei KH, Seyed Sharifi R, Pirzad A and Khalilzadeh R 2017. Effects of bio-fertilizer and nano Zn-Fe oxide on physiological traits, antioxidant enzymes activity and yield of wheat under salinity stress. J. Plant Interact. 12: 381-389.

Bano A and Fatima M 2009. Salt tolerance in Zea mays (L.) following inoculation with Rhizobium and pseudomonas Biol. Fert. Soils 45: 405-413.

Bates L, Waldren SRP and Teare ID 1973. Rapid determination of free proline for water stress studies. Plant and Soil 39: 205-207.

Bhattacharyya $\mathrm{P}$ and Jha D 2012. Plant growth-promoting rhizobacteria (PGPR): emergence in agriculture. World J. Microbiol. Biotechnol. 28: 1327-1350.

Bor M, Özdemir F and Türkan I 2003. The effect of salt stress on lipid peroxidation and antioxidants in leaves of sugar beet Beta vulgaris L. and wild beet Beta maritime L. Plant Sci. 164: 77-84.

Dröge W 2002. Free radicals in the physiological control of cell function. Physiol. Rev. 82: 47-95.

Dubois M, Gilles KA, Hamilton JK, Rebers PA and Smith F 1956. Colorimetric method for determination of sugars and related substances. Anal. Chem. 28: 350-356.

Feng G, Zhang FS, Li XL, Tian CY, Tang C, Rengel Z 2002. Improved tolerance of maize plants to salt stress by arbuscular mycorrhiza is related to higher accumulation of soluble sugars in roots. Mycorrhiza. 12: 185-190.

Gadallah MA 2000. Effects of indole-3-acetic acid and zinc on the growth, osmotic potential and soluble carbon and nitrogen components of soybean plants growing under water deficit. J. Arid. Environ. 44: 451-467.

Glassop D, Sally ES and Smith RW 2005. Cereal phosphate transporters associated with the mycorrhizal pathway of phosphate uptake into roots. Planta 222: 688-698.

Glick BR. 2012. Plant Growth-Promoting Bacteria: Mechanisms and Applications. Hindawi Publishing Corporation, Scientifica.

Guo Y, Ni Y and Huang J 2010. Effects of rhizobium, arbuscular mycorrhiza and lime on nodulation, growth and nutrient uptake of lucerne in acid purplish soil in China. Trop. Grass. 44: 109-114. 
Hashem A, Fathi Abd Allah E, Alqarawi AA, Aldubise A and Egamberdieva D 2015. Arbuscular mycorrhizal fungi enhances salinity tolerance of Panicum turgidum Forssk by altering photosynthetic and antioxidant pathways. J. Plant Interact. 10: 230-242.

Jeong J and Connolly EL 2009. Iron uptake mechanisms in plants: Functions of the FRO family of ferric reductases. Plant Sci. 176: 709-714.

Jodeh S, Alkowni R, Hamed R and Samhan S 2015. The study of electrolyte leakage from barley and pearlmillet using plant growth promotion (PGPR) and reverse osmosis. J. Food. Nutr. 3: 422-429.

Kapoor R, Evelin H, Mathur P and Giri B 2013. Arbuscular mycorrhiza: Approaches for abiotic stress tolerance in crop plants for sustainable agriculture. In: Tuteja, N., Gill, S.S (Eds). Plant acclimation to environmental stress. Springer LLC. pp. 359-401.

Karo M and Mishra, D 1976. Catalase, peroxidase, and polyphenoloxidase activities during rice leaf senescence. Plant Physiol. 57: 315-319.

Kaya K, Sonmez O, Aydemir S, Ashraf M and Dikilitas M 2013. Exogenous application of mannitol and thiourea regulates plant growth and oxidative stress responses in salt-stressed maize (Zea mays L.). J. Plant Interact. 8: 234-241.

Kheirizadeh Arough Y, Seyed Sharifi R, Sedghi M and Barmaki M 2016. Effect of zinc and bio-fertilizers on antioxidant enzymes activity, chlorophyll content, soluble sugars and proline in Triticale under salinity condition. Not. Bot. Hort. Agrobo. 44: 116-124.

Maxwell K and Johnson GN 2000. Chlorophyll fluorescence - A practical guide. J. Exp. Bot. 51: 659-668.

Miransari M. 2011. Interactions between arbuscular mycorrhizal fungi and soil bacteria. Appl. Microbiol. Biotechnol. 89: 917-930.

Mittova V, Tal M, Volokita M and Guy M 2003. Up-regulation of the leaf mitochondrial and peroxisomal antioxidative systems in response to salt-induced oxidative stress in the wild salt-tolerant tomato species Lycopersicon pennellii. Plant, Cell Environ. 26: 845-856.

Navari Izzo F, Quartacci MF and Izzo R 1990. Water stress induced changes in protein and free amino acids in field grown maize and sunflower. Plant Physiol. Biochem. 28: 531-537.

Netondo GW, Onyango JC and Beck E 2004. Sorghum and salinity. II. Gas exchange and chlorophyll fluorescence of sorghum under salt stress. Crop Sci. 44: 806-811.

Omar MNA, Osman MEH, Kasim WA and Abd El-Daim IA 2009. Improvement of salt tolerance mechanisms of barley cultivated under salt stress using Azospirillum brasilense. In: Ashraf, M. et al. (Eds.), Salinity and Water Stress. Springer Science+Business Media B.V., pp. 33-147.

Pereira WE, De Siqueira, DL, Martínez CA and Puiatti M 2000. Gas exchange and chlorophyll fluorescence in four citrus rootstocks under aluminium stress. Plant Physiol. 157: 513-520.

Premachandre GS, Saneoka H and Fujta K 1991. Osmotic adjustment and stomata response to water deficit in maize. J. Exp. Bot. 43: 1451-1456.

Qun HZ, Xing HC, Bin ZZ and Song WH 2007. Changes of antioxidative enzymes and cell membrane osmosis in tomato colonized by arbuscular mycorrhizae under $\mathrm{NaCl}$ stress. Colloids. Sur. B: Biointerfaces 59: 128-133.

Saito A, Shimizu M, Nakamura H, Katase R, Miwa E, Higuchi K and Sonoike K 2014. Fe deficiency induces phosphorylation and translocation of Lhcb1 in barley thylakoid membranes. FEBS Letters $\mathbf{5 8 8}$ : 2042-2048.

Sayar R, Khemira H, Kamel A and Mosbahi M 2008. Physiological tests as predictive appreciation for drought tolerance in durum wheat (Triticum durum Desf.). Agron. Res. 6: 79-90.

Seyed Sharifi R, Khalilzadeh R and Jalilian J 2016. Effects of biofertilizers and cycocel on some physiological and biochemical traits of wheat under salinity stress. Arch. Agron. Soil Sci. 63: 308-318.

Tambussi EA, Nogues S and Araus JL 2005. Ear of durum wheat under water stress: water relations and photosynthetic metabolism. Planta 221: 446-458.

Wang CJ, Yang W, Wang C, Gu C, Niu D, Wang Y and Guo JH 2012. Induction of drought tolerance in cucumber plants by a consortium of three plant growth-promoting rhizobacterium strains. Plos One 7: 552-565. 
WRB (World Reference Base for Soil Resources) 2014. International soil classification system for naming soils and creating legends for soil maps. World Soil Resources Reports 106. FAO, Rome.

Willis A, Rodrigues B and Harrisa PC 2013. The ecology of arbuscular mycorrhizal fungi. Crit. Rev. Plant Sci. 32: 1- 20.

Yordanov I, Velikova V and Tsonev T 2003. Plant responses to drought and stress tolerance. Bulg J. Plant Physiol. Special issue. 187-206.

Zago MP and Oteiza PI 2001. The antioxidant properties of zinc: Interactions with iron and antioxidants. Free Radic. Biol. Med. 31: 266-274.

Zayed BA, Salem Abd El-azeem K and Osama A 2014. Physiological characterization of Egyptian salt tolerant rice varieties under different salinity levels. Life Sci. J. 11: 1264-1272.

(Manuscript received on 21 February, 2018; revised on 12 June, 2018) 